\title{
Economic valuation of the ecosystem services provided by a protected area in the Brazilian Cerrado: application of the contingent valuation method
}

\author{
F. M. Resende ${ }^{a, b *}$, G. W. Fernandes ${ }^{a, c}$, D. C. Andrade and H. D. Néder $^{d}$ \\ ${ }^{a}$ Laboratório de Ecologia Evolutiva \& Biodiversidade, Departamento de Biologia Geral, \\ Universidade Federal de Minas Gerais - UFMG, \\ Avenida Presidente Antônio Carlos, 6627, Pampulha, CP 486, CEP 30161-970, Belo Horizonte, MG, Brazil \\ bLaboratório de Biogeografia da Conservação, Departamento de Ecologia, Instituto de Ciências Biológicas - ICB, \\ Universidade Federal de Goiás - UFG, Avenida Esperança, s/n, Câmpus Samambaia, CP 131, \\ CEP 74001-970, Goiânia, GO, Brazil \\ 'Department of Biology, Stanford University, Stanford CA 94305, USA \\ 'Instituto de Economia, Universidade Federal de Uberlândia - UFU, Avenida João Naves de Ávila, 2121, \\ Campus Santa Mônica, CEP 38408-100, Uberlândia, MG, Brazil \\ *e-mail: fermresende@gmail.com
}

Received: December 17, 2015 - Accepted: May 31, 2016 - Distributed: November 31, 2017

\begin{abstract}
Considering that the economic valuation of ecosystem services is a useful approach to support the conservation of natural areas, we aimed to estimate the monetary value of the benefits provided by a protected area in southeast Brazil, the Serra do Cipó National Park. We calculated the visitor's willingness to pay to conserve the ecosystems of the protected area using the contingent valuation method. Located in a region under intense anthropogenic pressure, the Serra do Cipó National Park is mostly composed of rupestrian grassland ecosystems, in addition to other Cerrado physiognomies. We conducted a survey consisting of 514 interviews with visitors of the region and found that the mean willingness to pay was $\mathrm{R} \$ 7.16$ year $^{-1}$, which corresponds to a total of approximately $\mathrm{R} \$ 716,000.00 \mathrm{year}^{-1}$. We detected that per capita income, the household size, the level of interest in environmental issues and the place of origin influenced the likelihood that individuals are willing to contribute to the conservation of the park, as well as the value of the stated willingness to pay. This study conveys the importance of conserving rupestrian grassland and other Cerrado physiognomies to decision makers and society.
\end{abstract}

Keywords: ecological economics, economic value, Espinhaço Mountains, rupestrian grasslands, willingness to pay.

\section{Valoração econômica de serviços ecossistêmicos fornecidos por uma área protegida no Cerrado brasileiro: aplicação do método de valoração contingente}

\begin{abstract}
Resumo
Dado que a valoração econômica de serviços ecossistêmicos é uma abordagem útil para incentivar a conservação de áreas naturais, tivemos como objetivo estimar o valor monetário dos benefícios fornecidos por uma área protegida no sudeste do Brasil, o Parque Nacional da Serra do Cipó. Calculamos a disposição a pagar dos visitantes pela conservação dos ecossistemas abrangidos pela área protegida, usando o método da valoração contingente. Localizado em uma região que sofre intensa pressão antrópica, o Parque Nacional da Serra do Cipó é composto majoritariamente por campos rupestres, além de outras fitofisionomias do Cerrado. Realizamos 514 entrevistas com os visitantes da região e encontramos uma disposição a pagar média de $\mathrm{R} \$ 7,16 \mathrm{ano}^{-1}$, o que corresponde ao total de aproximadamente $\mathrm{R} \$ 716.000,00 \mathrm{ano}^{-1}$. Detectamos que renda per capita, número de dependentes, nível de interesse por temas relacionados ao meio ambiente e local de origem influenciam a probabilidade de o indivíduo estar disposto a contribuir para a conservação do parque, assim como o valor da disposição a pagar declarada. Este estudo atrai atenção dos tomadores de decisão e da sociedade para a importância de se conservar os campos rupestres e outras fitofisionomias do Cerrado.
\end{abstract}

Palavras-chave: economia ecológica, valor econômico, Serra do Espinhaço, campos rupestres, disposição a pagar. 


\section{Introduction}

Human activities have dramatically impacted the planet's environment, changing the functioning of most of the ecosystems and threatening the global biodiversity (Crutzen, 2002; Rockstrom et al., 2009). Such disturbances have led to major impacts on ecosystem services, and consequently on human well-being (Foley et al., 2005; MEA, 2005). In face of such environmental crisis, the ecosystem services emerged as a key concept in strategic planning and environmental policy, being able to incentive cross-disciplinary research and link natural, human and economic systems (Lele et al., 2014; Schroter et al., 2014).

One important approach based on ecosystem services is the use of economic valuation techniques, which translate the services provided by ecosystems into monetary values. Economic valuation of ecosystem services is a useful tool to strength the efforts to conserve and manage natural ecosystems (De Groot et al., 2012; Costanza et al., 2014). Because it uses a metric that is easily understood (monetary units), economic valuation can increase society awareness about the importance of natural ecosystems in producing direct and indirect benefits that contribute to health, livelihood and economy (Figgis et al., 2015). In addition, economic valuation provides useful information for decision making and encourage investments in nature conservation (Goldman et al., 2008). For example, in many situations, the economic benefits arising from the maintenance of natural ecosystems can be higher than habitat conversion for the development of human activities (Balmford et al., 2002).

Although several environmental valuation studies exist (Costanza et al., 1997; De Groot et al., 2012), relatively few have focused on developing countries (Adams et al., 2008). Studies involving economic valuation in Brazil are rare. They are virtually absent for the Brazilian Cerrado (Resende et al., 2013), a tropical savanna with the richest flora in the world (Klink and Machado, 2005; Fernandes, 2016), and the region with the highest deforestation rates in Brazil in the last decades (Brasil, 2014).

Among the environmental valuation techniques, the contingent valuation method (CVM) is one of the most preferred by practitioners of valuation and has a long history that began in early 1960s (Carson et al., 1994; Hoyos and Mariel, 2010). Using market simulations and the econometric treatment of collected information, the CVM is able to estimate the monetary value of the preferences of individuals regarding the conservation or restoration of a particular environmental good (Maia et al., 2004). As noted by Arrow et al. $(1993$, p. 3) in the Report of the NOAA (National Oceanic and Atmospheric Administration) Panel on Contingent Valuation, this technique "[...] is based on the direct elicitation of these values from individuals through the use of carefully designed and administered sample surveys."

Although the CVM has been used for various purposes (Arrow et al., 1993; Barrio and Loureiro, 2010), there is an intense debate among different economic schools of thought regarding its use (Diamond and Hausman, 1994; Spash, 2008). As the CVM is based on assumptions of mainstream economic theory, neoclassical economists believe this method is a valid and useful tool, while some economists view it as a restricted tool. Ecological economists, for example, suggest using caution when applying the CVM because it is based on reductionist assumptions about the behavior of economic agents (Andrade and Romeiro, 2013). Ecological economics is a multidisciplinary branch of economics that has proposed a comprehensive redesign of the assumptions on which economic thought is based (Daly and Farley, 2004). It criticizes the belief that the economic system can grow uninterruptedly (Georgescu-Roegen, 1971; Coelho et al., 2013).

Considering that the use of valuation techniques is useful for supporting the conservation of natural areas, we aimed to estimate the monetary value of the benefits provided by the ecosystems of the Serra do Cipó National Park (SCNP). Using the CVM, we calculated visitors' willingness to pay (WTP) for the conservation of the ecosystems within the protected area. We intended to answer the following questions: i) Considering the ecosystem services provided by the SCNP, what is the economic value that visitors of the Serra do Cipó are willing to pay annually to conserve the protected area? ii) What are the socioeconomic characteristics and level of environmental awareness exhibited by the visitors of the Serra do Cipó? iii) What are the factors (related to socioeconomic characteristics and environmental awareness) that influence the answers related to the stated WTP by the respondent? Furthermore, we provide a brief analysis of the CVM from the perspective of ecological economics and noted some methodological guidelines that may be helpful in overcoming the biases presented by this technique.

\section{Methods}

\subsection{Study area}

The SCNP is located in the southern area of the Espinhaço Range, southeast Brazil (Minas Gerais State); it covers an area of 31,617 hectares (ICMBio, 2009). Although the predominant biome in the region is the Cerrado (the Brazilian savanna), there are also ecosystems related to the Atlantic Forest (e.g., tropical dry forest on limestone outcrops) (Coelho et al., 2012). The rupestrian grassland ecosystems are the predominant vegetation type in the region (Giulietti et al., 1987; Madeira et al., 2008). This vegetation type is typically composed of herbaceous and shrub strata (Rapini et al., 2008; Ribeiro and Walter, 2008), and is internationally recognized for its biological importance, particularly with respect to the richness and endemism of its flora (Giulietti et al., 1997; Silveira et al., 2016; Fernandes, 2016).

The region covers a significant number of river headwaters, ensuring the provision of water to the local population, as well as the supply of rivers of high national importance, i.e., the São Francisco River and the Doce River. Additionally, the Serra do Cipó is an important tourism hub of the State of Minas Gerais (ICMBio, 2009; Campos and Filetto, 2011). According to calculations by the Department of Tourism and Environment of Santana do Riacho municipality, approximately 100,000 tourists annually visit the Serra do Cipó. 
Despite their importance, ecosystems in the Serra do Cipó are critically threatened (ICMBio, 2009; Fernandes et al., 2014; Fernandes, 2016). The construction of residential condominiums and urban infrastructure have intensified recently, leading to a disordered occupation and conversion of natural areas. Tourism activities have also expanded (Ferreira and Gontijo, 2010) and introduced problems, such as solid waste and erosion of trails. These activities have also been accompanied by the construction of highways, which cause the loss and isolation of natural habitats and promote biological invasions (Barbosa et al., 2010; Fernandes, 2016).

\subsection{Contingent valuation method}

Approaches based on WTP are capable of capturing, via surveys, information related to the voluntary economic sacrifice of agents for the maintenance of an environmental resource or a particular environmental program (Arrow et al., 1993). The hypothetical market is built such that the interviewees can declare their true preferences and faithfully reflect their decisions if there was a market for the good or ecosystem service (Motta, 1997). The characteristics of the natural resource to be valued are presented before the respondents are asked about their WTP to preserve the area under evaluation. Thus, the interviewees have access to a range of information to formulate their preferences in relation to the good that is under valuation. Among other reasons, the interest and use of the CVM are large due to its flexibility and adaptability to different situations and also because it is the only method that is able to capture the existence value of natural resources (Motta, 1997; Maia et al., 2004).

\subsection{Sample selection and interviews}

To estimate the WTP for the conservation of the SCNP, we conducted a survey consisting of 514 interviews with visitors to the region. We applied a questionnaire with predefined questions at the two entrances to the SCNP (45.3\% of the interviews) and in places near the park with high volumes of tourists (along highway MG-10; 54.7\% of the interviews).

We conducted the questionnaires individually, selecting only one person within each group of tourists. The group and person in that group interviewed were selected haphazardly, i.e., without considering any specific characteristic. We conducted the interviews on weekends and holidays from April 2012 to June 2012 for a total of 14 days of surveys. Weekends and holidays were chosen because the tourism is more intense in these periods (ICMBio, 2009; Campos and Filetto, 2011). The time spent to complete each questionnaire was approximately ten minutes. The field data were collected by the lead author of the study and by an academic from the humanities field, who received appropriate guidance. We distributed 22 questionnaires as a pre-test to adjust the final questionnaire. The pre-test questionnaires were discarded after analysis.

The initial section of the final questionnaire concerned the socioeconomic aspects of the interviewee, including aspects such as educational level, profession, place of origin, family income and number of dependents (household size).
We then presented a description of the SCNP, including the ecological and societal importance of the region. We then asked the respondent if it is important to preserve the protected area. For positive responses, we inquired why the interviewee considers the park's conservation important (open question).

Subsequently, we asked whether the respondent is willing to contribute financially to the conservation of the SCNP through a voluntary program. Our hypothetical market assumed each person who exhibited a positive WTP should annually pay a specific amount to an association involved with the conservation of the SCNP, organized by the managing agency of the park (Chico Mendes Institute for Biodiversity Conservation - ICMBio), a well-known public university (Federal University of Minas Gerais - UFMG), and the local population. Such an association would be responsible for managing the funds collected for the conservation of the park's ecosystems. The funds would be collected via bills mailed annually to interested people. For the elicitation form, we used the mechanism of payment card. We showed the respondent ten values in multiples of five between $\mathrm{R} \$ 5.00$ and $\mathrm{R} \$ 50.00$ (1 R $\$=U S \$ 0.50$, in 15th May 2012) and asked them to choose the amount they were willing to pay.

Following the approach used by Adams et al. (2008), we investigated what type of economic value the respondents considered most important in their stated WTP. Natural resources have at least three types of economic values (Maia et al., 2004). The existence value, which is related to the right to exist of species and natural resources without considering the benefits they can provide. The option value, which relates to the value that is assigned by the people in the present to the future benefits that natural ecosystems can provide. The use value, which corresponds to the benefits generated by natural resources that are directly appropriated by society or that benefits humans indirectly from ecosystem functions. The respondents were asked to select the statement that best described their response. For the existence value, the reason given in the questionnaire was that species and ecosystems have the right to exist, regardless of their utility, i.e., even if they do not provide current or future benefits for the visitor or society. For the option value, the information presented was that by conserving the park, the visitors and their families could enjoy the future benefits generated by its species and ecosystems. Finally, for the use value, the argument was that the conservation of the park would allow immediate enjoyment of its attractions and amenities.

For those who did not present any WTP, we asked for their rationales. We asked all of the respondents how often they visit the park each year. We also evaluated the degree of environmental perception of the respondents by questioning their level of interest in topics related to the environment, as well as the importance assigned to environmental conservation in Brazil and the perception of the level of concern of the Brazilian government for nature conservation in the country. To evaluate the comprehension of the questionnaire, we asked the respondents whether they found the questionnaire easy or difficult to understand. These questions were based on Adams et al. (2008). 
To understand the effect of the variables on the likelihood that individuals are willing to contribute to the conservation of the park, we used the logit model, which is a regression based on the cumulative logistic function (Pindyck and Rubinfeld, 2009). This model provides a suitable fit for binary choice situations (Hill et al., 2006), in which the dependent variable can assume only two values. In this study, it is related to the WTP, which can have the value of 1 (the individual is willing to pay, i.e., $\mathrm{WTP}>0$ ) and 0 (the individual is not willing to pay, i.e., $\mathrm{WTP}=0$ ). We evaluated the willingness of a person to pay as a function of several continuous variables, i.e., age (years), family income (R $\$ /$ month), per capita income (R\$/month), number of dependents (household size), and categorical variables (e.g., sex, educational level, and place of origin) (Table 1).

We also evaluated the effect of the variables on the value of the informed WTPs. For those people who are not willing to contribute to the conservation of the park, the WTP value is zero. We used the tobit model because the dependent variable is censored, i.e., the information of the dependent variable is cut off at zero (Gujarati, 2000; Pindyck and Rubinfeld, 2009). This model avoids biases that could occur if a simple model of multiple linear regressions was used because of the high occurrence of zero values in the dependent variable. The tobit model uses the maximum likelihood method to estimate the parameters, and it considers two groups: the censored observations and others (Hill et al., 2006). We assessed the value of the stated WTP as a function of the same variables considered in the logit model. For both analyses (logit e tobit), we tested several variable sets to choose the model with the most adequate specifications.

In the econometric analyses (both models), we did not consider the protest votes, i.e., those individuals who were unwilling to pay because they believe the government is responsible for preservation or those who believe that they already bear a high tax burden (79 people or $15.4 \%$ ). Therefore, we used the information of 435 people. This approach was also conducted by Adams et al. (2008); it is justified because the analyses with such observations could be biased, i.e., these individuals did not declare their preferences due to external reasons that are unrelated to conservation.

To calculate the aggregate WTP, we considered the mean individual WTP value predicted by the tobit model. This value refers to the mean of all sample predictions. We calculated the predicted value for each observation from the following Equation 1:

$\hat{y}_{i}=\hat{\beta}_{0}+\hat{\beta}_{1} \times x_{1 i}+\hat{\beta}_{2} \times x_{2 i}+\ldots+\hat{\beta}_{p} \times x_{p i}$

where $\hat{y}_{i}$ is the prediction concerning the observation $i ; \hat{\beta}_{0}$, $\hat{\beta}_{1}, \hat{\beta}_{2}, \ldots, \hat{\beta}_{p}$ are the estimated parameters for the model; $x_{1 i}, x_{2 i}, \ldots, x_{\mathrm{p} i}$, are the observed values of observation $i$ for the explanatory variables $1,2, \ldots p$.

Because of multicollinearity in the models, we removed the level of education and perception of the Brazilian government variables. We used a robust estimation that corrects the bias estimation of standard errors caused by heteroscedasticity. We used Stata 12.0 software for the econometric analyses.

Table 1. Categorical variables related to socioeconomic characteristics and environmental awareness of visitors to the Serra do Cipó region.

\begin{tabular}{ll}
\hline \multicolumn{1}{c}{ Variable } & \multicolumn{1}{c}{ Unit/categories used } \\
\hline Sex & $0-$ Female \\
& $1-$ Male \\
Visited the SCNP & $0-$ No \\
& $1-$ Yes \\
Education & $0-$ No formal education \\
& $1-$ Complete primary/ \\
& secondary school \\
& $2-$ Incomplete primary/ \\
& secondary school \\
& $3-$ Complete high school \\
& $4-$ Incomplete high \\
& school \\
& $5-$ Complete \\
& undergraduate school \\
& $6-$ Incomplete \\
& undergraduate school \\
& $7-$ Complete graduate \\
& school \\
& $8-$ Incomplete graduate \\
school
\end{tabular}

Interest in environmental 0 -Great interest issues

1 - Interest

2 - little interest

3 - Not interested

Importance of

0 - Very important

conservation

1 - Important

2 - Slightly important

3 - Not important

Government concern for $\quad 0$ - Cares a lot conservation

1 - Cares

2 - Cares little

3 - Does not care at all

4 - Interviewee is unsure

Place of origin $\quad 0$ - City of Belo

Horizonte

1 - Espírito Santo State

2 - Minas Gerais State

3 - other states

4 - other countries

5 - Rio de Janeiro State

6 - metropolitan region of

Belo Horizonte

7 - Serra do Cipó region

8 - São Paulo State 


\section{Results}

\subsection{Profile of interviewed public}

Of the respondents, the number of men (256 or $49.8 \%)$ and women ( 258 or $50.2 \%$ ) were approximately equal. They are from different localities (59 municipalities), but most live in Belo Horizonte (67.1\%) or in its metropolitan region (15.6\%) (Table 2 ). The majority were adults (mean $=35.98$ years old, standard deviation $=11.6$ ) with a relatively high level of education (Table 2). The mean household income was R\$ 6,120.00 per month, ranging from $\mathrm{R} \$ 500.00$ to $\mathrm{R} \$ 40,000.00$. Considering the mean number of dependents (2.73 people), the mean per capita income was $\mathrm{R} \$ 2,497.75$.

The majority of the respondents $(63 \%)$ had visited the park at least once, either during the days of the interview or previously. All of them stated that there are reasons for the conservation of the SCNP. The main reason $(58.4 \%)$ was the importance of the park for the conservation of biodiversity, followed by the protection of water resources $(30.2 \%)$, its attractiveness (22.4\%), the preservation of the environment $(20.9 \%)$ and the intense anthropogenic pressure on nature $(20 \%)$. Other reasons given were that the SCNP is part of nature $(11.9 \%)$, nature is important for humans $(9.1 \%)$, the park is relevant for future generations $(8.7 \%)$ and it has historical and cultural importance (7\%).

When asked about their interest in environmental issues, the majority of the respondents reported great interest $(50.2 \%)$ or interest $(44.4 \%)$ in issues related to the environment (Table 3). The entire sample indicated that the conservation of the environment in Brazil is very

Table 2. Socioeconomic characteristics of the interviewees in the Serra do Cipó, Minas Gerais.

\begin{tabular}{llcr}
\hline & & Number of respondents & $\begin{array}{c}\text { Percentage } \\
\text { (\%) }\end{array}$ \\
\hline Place of origin & & 0.6 \\
& Serra do Cipó region & 3 & 67.1 \\
& City of Belo Horizonte & 345 & 15.6 \\
& Metropolitan region of Belo & 80 & 11.3 \\
& Horizonte & & 2.1 \\
& Minas Gerais State & 58 & 1.8 \\
Rio de Janeiro State & 11 & 0.4 \\
& São Paulo State & 9 & 1.0 \\
& Espírito Santo State & 2 & 0.2 \\
Other states & 5 & 0.2 \\
Other countries & 1 & 2.7 \\
& & 1 & 1.4 \\
No formal education & 14 & 22.2 \\
Complete primary/secondary school & 7 & 0.8
\end{tabular}

Table 3. Environmental awareness of the interviewees in the Serra do Cipó, Minas Gerais.

\begin{tabular}{llc}
\hline \multicolumn{1}{c}{ Question } & \multicolumn{1}{c}{ Answer } & Percentage (\%) \\
\hline Interest in environment issues & Great interest & 50.2 \\
& Interest & 44.4 \\
& Little interest & 5.4 \\
& Not interested & 0.0 \\
Importance of conservation & Very important & 91.8 \\
& Important & 8.2 \\
& Slightly important & 0.0 \\
Government concern for conservation & Not important & 0.0 \\
& Cares a lot & 1.2 \\
& Cares & 18.1 \\
& Cares little & 54.9 \\
& Does not care at all & 25.7 \\
\hline
\end{tabular}


important $(91.8 \%)$ or important $(8.2 \%)$. The majority of the respondents stated that the Brazilian government bears little (54.9\%) to no concern $(25.7 \%)$ for conservation. Most respondents $(97.7 \%)$ believed the questionnaire was easy to understand, which demonstrates that it was appropriate for the characteristics of the target audience.

\subsection{Willingness to pay}

The proportion of the respondents willing to pay $(51.4 \%$ or 264 persons) was higher than those who said they are not willing ( $48.6 \%$ or 250 people). Among the people who were willing to contribute, $39.77 \%$ and $39.39 \%$ indicated that issues associated with the existence and option value is the main reason for their WTP, respectively. The remaining $(20.83 \%)$ referred to the use value.

The main reason given by the respondents unwilling to contribute was related to the biased views of the government $(31.6 \%)$. Included in this category are those who consider conservation a responsibility of the government $(28.0 \%)$ and those who believe they are already paying too many taxes and fees (3.6\%). Other frequently reported reasons were financial $(16.8 \%)$ or their commitment to other forms of conservation (15.2\%). Those who claimed that they are not interested in the conservation project of the SCNP represent only $4.4 \%$ of the sample.

The mean individual WTP predicted by the tobit model (via Equation 1, which consider both respondents willing and unwilling to pay) regarding the conservation of the SCNP was R \$ 7.16 per person annually. Considering the average number of visitors to the SCNP and surrounding areas $\left(100,000\right.$ year $\left.^{-1}\right)$, the total benefits provided by the park was valued at approximately $\mathrm{R} \$ 716,000.00$ year $^{-1}$. Taking into account the SCNP area (31,617 hectares), the benefits provided per hectare are $\mathrm{R} \$ 22.65$ year $^{-1}$.

\subsection{Influences of socioeconomic variables}

To assess the effect of the variables on the likelihood of an individual having a WTP, we selected the model with the following variables: age, per capita income, number of dependents, interest in topics related to the environment, place of origin, previous or no visits to the SCNP and the relationship between interests and place of origin (logit model; Table 4). The increase in per capita income had a positive influence on the likelihood of an individual having a WTP (odds ratio $=1.494, \mathrm{p}=0.018$ ). An increase of $1 \%$ in per capita income led to a mean increase of $49 \%$ in the odds ratio related to the WTP, ceteris paribus. The increase in the number of dependents also led to an increase in the likelihood of an individual having a WTP (odds ratio $=1.2005, \mathrm{p}=0.034$ ).

Tourists with little interest in topics related to the environment were less likely to be willing to pay than those who have a high interest (odds ratio $=0.2434, \mathrm{p}=0.018$ ) (Table 4). The respondent's place of origin also had an impact. Tourists from the State of Rio de Janeiro were less likely to have a WTP compared with those of Belo Horizonte (odds ratio $=4.02 \times 10^{-7}, \mathrm{p}<0.001$ ). Additionally, the degree of interest in environmental issues and place of origin were related, which means these variables interact to increase the WTP likelihood. The people who have an interest in environmental topics and that live in Rio de Janeiro were more likely to be willing to pay than those from Belo Horizonte who have a great interest in environmental topics (odds ratio=521,292.2, $\mathrm{p}<0.001$ ).

To assess the influence of the variables on the reported values of the WTP, we considered the model with the following variables: age, per capita income, number of dependents, interest in environmental topics, place of origin, previous or no visits to the SCNP and the interaction between interests and place of origin (tobit model; Table 5). Increasing age had a negative influence on the WTP value (coefficient $=-23.0846, \mathrm{p}<0.001$ ), which means that older people were less willing to contribute, ceteris paribus. The increase in per capita income (coefficient $=6.463$, $\mathrm{p}<0.001$ ) and the number of dependents (coefficient $=1.940$, $\mathrm{p}<0.001)$ led to an increase in the WTP value. People who had previously visited the SCNP tended to pay more than those who have never entered the park (coefficient $=4.414$, $\mathrm{p}<0.001$ ). Those people with little interest in issues related to the environment had a lower WTP $(\mathrm{R} \$ 23.08$ on average $)$ for the conservation of the park (coefficient $=-23.087$, $\mathrm{p}<0.001$ ) when compared with people with high interest.

The person's place of origin also had a significant effect on the value of the WTP, but it was not possible to observe a clear pattern between the different regions. There was also a significant interaction between the level of interest in environmental topics and the place of origin of the respondent.

\section{Discussion}

In the present study, we calculated the annual WTP of visitors to preserve the SCNP (R\$ 716,000.00 year ${ }^{-1}$ or R\$22.65 $\mathrm{ha}^{-1}$ year $^{-1}$ ) and defined the socioeconomic variables that influence the answers related to the stated WTP by the respondent. This value reveals in a monetary metric the importance that visitors assigned to the park regarding the services supplied by its ecosystems and include all three value categories associated by natural assets (existence value, option value and use value). The value calculated here does not refer to an economic amount that can be appropriated directly by the community, nor does it reflects the market value of the SCNP.

Arguments provided by economic valuation for maintaining the protected areas in Brazil are of utmost importance because in recent years, there have been numerous cases in which protected areas were reduced to enable the development of economic activities. According to Bernard et al. (2014), between 1981 and 2012, Brazilian protected areas lost approximately 5.2 million hectares, which further threatens biodiversity and natural ecosystems. Additionally, as presented by Medeiros et al. (2011), the amount invested in Brazil per hectare of protected area is far from ideal, being 25 times lower than the amount invested by other countries, including those with lower gross domestic products than Brazil. Studies that demonstrate 
Table 4. Results related to the estimation of the logit model (dependent variable: 1 for the individuals who have a WTP; 0 for those not featuring any WTP).

\begin{tabular}{|c|c|c|c|c|}
\hline Explanatory variable & Odds ratio & $\begin{array}{c}\text { Robust } \\
\text { standard error }\end{array}$ & $\mathbf{Z}$ & $\mathbf{P}>|\mathbf{z}|$ \\
\hline Age & 0.9857 & 0.0087 & -1.61 & 0.107 \\
\hline Per capita income ${ }^{\mathrm{a}}$ & 1.4936 & 0.2525 & 2.37 & 0.018 \\
\hline Number of dependents & 1.2005 & 0.1032 & 2.12 & 0.034 \\
\hline Visited the SCNP & 1.3685 & 0.3016 & 1.42 & 0.155 \\
\hline Interest in environmental issues & 0.9838 & 0.2565 & -0.06 & 0.950 \\
\hline Little interest & 0.2434 & 0.1447 & -2.38 & 0.018 \\
\hline Espírito Santo State & 1 & $* *$ & & \\
\hline Minas Gerais State & 2.0126 & 0.9873 & 1.43 & 0.154 \\
\hline Other states & 1 & $* *$ & & \\
\hline Other countries & 1 & $* *$ & & \\
\hline Rio de Janeiro State & $<0.0001$ & $<0.0001$ & -29.18 & $<0.001$ \\
\hline $\mathrm{MRBH}$ & 1.1022 & 0.4428 & 0.24 & 0.809 \\
\hline Serra do Cipó region & 1 & $* *$ & & \\
\hline São Paulo State & 0.3120 & 0.3817 & -0.95 & 0.341 \\
\hline Interest*Espírito Santo State & 1 & $* *$ & & \\
\hline Interest*Minas Gerais State & 0.4455 & 0.3121 & -1.15 & 0.248 \\
\hline Interest*other states & 1 & $*$ & & \\
\hline Interest*other countries & 1 & $*$ & & \\
\hline Interest*Rio de Janeiro State & $521,292.2$ & 678,872 & 10.11 & $<0.001$ \\
\hline Interest*MRBH & 1.0786 & 0.6230 & 0.13 & 0.896 \\
\hline Interest*Serra do Cipó State & 1 & $*$ & & \\
\hline Interest*São Paulo State & 2.9312 & 4.3560 & 0.72 & 0.469 \\
\hline Little interest*Espírito Santo State & 1 & $*$ & & \\
\hline Little interest*Minas Gerais State & 1 & $* *$ & & \\
\hline Little interest*other states & 1 & $*$ & & \\
\hline Little interest*other countries & 1 & $*$ & & \\
\hline Little interest*Rio de Janeiro State & 1 & $*$ & & \\
\hline Little interest*MRBH & 3.0708 & 3.5325 & 0.98 & 0.329 \\
\hline Little interest*Serra do Cipó region & 1 & $*$ & & \\
\hline Little interest*São Paulo State & 1 & $*$ & & \\
\hline Constant & 0.0628 & 0.0848 & -2.05 & 0.040 \\
\hline $\begin{array}{l}\text { Number of observations: } 413 \\
\text { Pseudo } \mathrm{R}^{2}=0,0581 \\
\text { Log pseudo likelihood }=-262,1 \\
\text { Sensibility }=93,12 \\
\text { Specificity }=23,49\end{array}$ & & & & \\
\hline
\end{tabular}

${ }^{\text {a }}$ Log of per capita income; * Omitted variable due to multicollinearity; ** Omitted variable by perfectly predicting the success; $\mathrm{MRBH}$ - metropolitan region of Belo Horizonte.

the value of the ecosystems to society and government in Brazil are primordial in a period where actions made by policy and decision makers have been inconsistent with the Brazilian important natural heritage (Loyola, 2014).

Contingent valuation studies developed in Brazil reported a considerable range of values. In the present study, we estimated the mean individual WTP regarding conservation of the services supplied by the SCNP in R\$ 7.16 per person annually. Adams et al. (2008) reported that the annual WTP of the residents of São Paulo was US\$ 1.58 per individual regarding the conservation of Morro Diabo State Park (São Paulo). However, other studies reported higher values, such as Carvalho (2007), who estimated that the mean WTP for the restoration and preservation of the Upper Paraná River floodplain was US\$ 33.00 year $^{-1}$, considering its use for leisure activities. In a study conducted in the Pantanal, Moran and Moraes (2002) found a WTP of US\$ 61.58 based on open elicitation and US\$ 159.90 based on the referendum method (dichotomous choice). The variability in the WTP values may reflect the different approaches used and differences related to environmental awareness, which may hinder a comparison among different studies.

The WTP found in this study might be underestimated because respondents may have only considered a smaller area of the SCNP than the actual area $(31,617 \mathrm{ha})$. 
Table 5. Results related to the estimation of the tobit model (dependent variable: WTP value).

\begin{tabular}{|c|c|c|c|c|}
\hline Explanatory variable & Coefficient & $\begin{array}{c}\text { Robust } \\
\text { standard error }\end{array}$ & $\mathbf{t}$ & $\mathbf{P}>|\mathbf{t}|$ \\
\hline Age & -0.2446 & 0.0204 & -11.94 & $<0.001$ \\
\hline Per capita income ${ }^{a}$ & 6.4631 & 0.1111 & 58.20 & $<0.001$ \\
\hline Number of dependents & 1.9396 & 0.2260 & 8.58 & $<0.001$ \\
\hline Visited the SCNP & 4.4139 & 0.7175 & 6.15 & $<0.001$ \\
\hline Interest in environmental issues & -0.4103 & 0.7312 & -0.56 & 0.575 \\
\hline Little interest & -23.0846 & 0.7934 & -29.10 & $<0.001$ \\
\hline Espírito Santo State & 32.9093 & 0.5941 & 55.39 & $<0.001$ \\
\hline Minas Gerais State & 5.8204 & 0.8892 & 6.55 & $<0.001$ \\
\hline Other states & 19.2982 & 0.5335 & 36.17 & $<0.001$ \\
\hline Other countries & 12.1135 & 0.7181 & 16.87 & $<0.001$ \\
\hline Rio de Janeiro State & -168.8327 & 7.5889 & -22.25 & $<0.001$ \\
\hline $\mathrm{MRBH}$ & -1.5807 & 0.8559 & -1.85 & 0.065 \\
\hline Serra do Cipó region & 10.7161 & 0.6859 & 15.62 & $<0.001$ \\
\hline São Paulo State & -23.3525 & 2.8368 & -8.23 & $<0.001$ \\
\hline Interest*Espírito Santo State & -196.1985 & $* *$ & & \\
\hline Interest*Minas Gerais State & -7.0258 & 1.1902 & -5.90 & $<0.001$ \\
\hline Interest*other states & 0 & $*$ & & \\
\hline Interest*other countries & 0 & $*$ & & \\
\hline Interest*Rio de Janeiro State & 154.8737 & 7.5889 & 20.41 & $<0.001$ \\
\hline Interest*MRBH & -0.2392 & 1.0967 & -0.22 & 0.827 \\
\hline Interest*Serra do Cipó region & 0 & $*$ & & \\
\hline Interest*São Paulo State & 29.1669 & 3.2130 & 9.08 & $<0.001$ \\
\hline Little interest*Espírito Santo State & 0 & $*$ & & \\
\hline Little interest*Minas Gerais State & 50.6857 & 1.7945 & 28.25 & $<0.001$ \\
\hline Little interest*other states & 0 & $*$ & & \\
\hline Little interest*other countries & 0 & $*$ & & \\
\hline Little interest*Rio de Janeiro State & 0 & * & & \\
\hline Little interest*MRBH & 15.8203 & 1.8458 & 8.57 & $<0.001$ \\
\hline Little interest*Serra do Cipó State & 54.5723 & 1.3828 & 39.46 & $<0.001$ \\
\hline Little interest*São Paulo State & 0 & $*$ & & \\
\hline Constant & -38.1011 & 0.8545 & -44.59 & $<0.001$ \\
\hline $\begin{array}{l}\text { Number of observations: } 423 \\
\text { Pseudo } \mathrm{R}^{2}=0.0181 \\
\text { Log pseudo likelihood }=-1,319\end{array}$ & & & & \\
\hline
\end{tabular}

${ }^{\text {a }}$ Log of per capita income; * Omitted variable due to the small number of observations in the sample; ** The coefficient was calculated, but the calculation of the standard error was not possible (the variable was not omitted from the model); $\mathrm{MRBH}$ - Metropolitan region of Belo Horizonte.

Specifically, only a portion of the park can be accessed by tourists (due to the long hiking distances and the difficulty to access them). Moreover, the respondents are likely not aware of all the services provided by the SCNP ecosystems, despite the range of services that were presented in the questionnaires. One of the difficulties inherent in contingent valuation studies is the accurate description of environmental attribute complexes within the few minutes of the survey completion.

In this study, the percentage of people with null values for WTP was relatively high, but other studies conducted in Brazil found similar results. For example, in a study focusing on the Morro Diabo State Park (São Paulo), $65.1 \%$ of respondents had no WTP (Adams et al., 2008).
The high proportion of zero responses suggests high levels of protest against the government's views or to possible tax and fee increases (Adams et al., 2008). This is possibly a result of the perception of the mismanagement of public funds and a high tax burden in Brazil; these aspects are common knowledge in the Brazilian society.

The discrepancy between the degree of importance that people assign to the conservation and the concern they have on the Brazilian government has for environmental issues is notorious. This may indicate that the public's attention to environmental issues is a parameter of increasing importance for assessing the performance of governments at various levels (national, state and municipal). 


\subsection{Influences of socioeconomic variables}

We observed that per capita income, number of dependents, interest in topics related to the environment and place of origin had a significant influence on the likelihood of an individual having a WTP (logit model; Table 4). The increase in both per capita income and the number of dependents had a positive influence on WTP. It is intuitive and consistent with previous CVM studies that individuals with higher incomes have a greater ability to pay and are more willing to designate part of their income to conservation projects (Jacobsen and Hanley, 2009). On the other hand, the positive relationship between number of dependents and WTP is not commonly demonstrated in CVM studies (e.g., Amin and Koné, 2015). We understand that those who are part of larger families may be more willing to contribute to conservation to ensure a better quality of life for their relatives.

As expected, people who declared little interest in the environment might do not recognize the importance of conserving natural ecosystems and consequently are less willing to pay for conservation. Similar results were reported in South Africa (Turpie, 2003), where people more interested in nature were also more willing to contribute. Although people from the State of Rio de Janeiro were less likely to have a WTP compared with those of Belo Horizonte, as the value of the odds ratio coefficient is practically zero, the effect of the variable was practically negligible.

Analyzing the variables that had an influence on the WTP value, we observed that age, per capita income, number of dependents, previous or no visits to the SCNP and interest in issues related to the environment had a significant effect (tobit model; Table 5). The negative influence of age was also reported previously in some CVM case studies (e.g., Adams et al., 2008) and can be associated with the fact that older generations are less exposed to conservationist arguments. On the other hand, the increase in per capita income and the number of dependents led to an increase in the WTP value; the same reasons pointed out above can be also applied in this case.

People who had previously visited the SCNP tended to pay more. As suggested by Turpie (2003), experience in visiting protected areas might increase the interest of people in conservation. Thus, those who already knew the natural beauty of the park and benefited directly from its services are willing to contribute more than those who have never entered the park. It suggests that visiting the natural areas can help citizens recognize the importance of natural areas as ecosystem services suppliers and the relevance of nature for humanity.

\subsection{The ecological economics and the CVM}

Conventional valuation techniques, such as contingent valuation, are based on the idea of "Homo economicus", which assumes that humans are able to make choices based solely on rationality and that have full knowledge of the consequences of their actions (Persky, 1995; Costanza, 2000; Andrade and Romeiro, 2013). Adopting this hypothesis, neoclassical economists assume that humans are able to understand the complexity underlying the interrelationships between environmental attributes and that human preferences can be correctly determined (Mirowski, 1989).

For ecological economics researchers, the human behavior of neoclassical economics is too reductionist. Ecological economists believe that humans are naturally limited, have bounded rationalities and are not able to attain a holistic understanding (Van den Bergh, 2001). Therefore, one of the main criticisms against conventional valuation techniques (especially the CVM) is that respondents would not be able to understand all the issues that are debated or the inherent complexity of ecosystems (Vatn and Bromley, 1994). To overcome these limitations, the description of the object of valuation and the interactions between the components of ecosystems is fundamental to the CVM application process

We suggest that the contingent valuation could be preceded by an ecosystem assessment in which an ecological-economic model is used with the explicit purpose of facilitating the communication between the interviewer and interviewees. Ecological or ecosystem models are able to represent in a simplified form the inter-relationships between the structural elements of ecosystems (Wätzold et al., 2006; Voinov, 2008). It is also possible to add human impacts to ecological models (Costanza et al., 1993); what enhance the understanding of the dynamics of ecological systems and the possible effects of human activities.

Using the modeling outcomes during the contingent valuation survey could provide more concrete information to respondents, who can then more correctly assess the questions with less subjectivity. Ecological-economic models would be useful for demonstrating how the dynamics of the ecosystem services are generated by a particular natural area and the influence of human actions on the environment. Such information is relevant to the respondents so that they can state their preference in a more correct and proper way.

\section{Concluding Remarks}

Valuation studies can be useful for demonstrating the importance of the SCNP, providing arguments for the government to allocate more resources to the conservation of the area or creating other protected areas in regions with similar environmental characteristics. The approach used in this study allowed us to partially capture values associated with three types of values of natural resources (use value, option value, and existence value). We contributed to expand the analysis focused in the ecosystem services provided by the threatened ecosystems of Serra do Cipó. Previously, Resende et al. (2013), using the method of replacement cost, estimated the monetary value of plant diversity storage service provided by the SCNP ecosystems as US\$25.26 million year ${ }^{-1}$. For consistency regarding the inherent complexity of natural ecosystems, efforts are 
still needed to capture the other dimensions of ecosystem values (ecological and socio-cultural dimensions) of SCNP ecosystems.

We suggest that possible enhancements to the contingent valuation method should be coupled with the improving the perception of the respondents to increase the confidence of the responses. Economic-ecological models could serve this purpose.

Rupestrian grassland ecosystems and the Cerrado provide several ecosystem services even after a long history of unsustainable use of the resources. When properly maintained, these services provide indefinite direct and indirect benefits to society.

\section{Acknowledgements}

We thank RFPS Paiva, AP Paglia, and MS Coelho for their contributions to the improvement of the study and two anonymous reviewers for their comments on the manuscript. We thank E Almada and R Azevedo for the critical analysis and application of the questionnaire, respectively. We also thank the SCNP/ICMBio and Reserva Velozia for the logistical support. The study was supported by CNPq/Peld/ComCerrado and FAPEMIG (EDT-465/07, APQ-04105-10).

\section{References}

ADAMS, C., MOTTA, R.S., ORTIZ, R.A., REID, J., AZNAR, C.E. and SINISGALLI, P.A.D., 2008. The use of contingent valuation for evaluating protected areas in the developing world: economic valuation of Morro do Diabo State Park, Atlantic Rainforest, Sao Paulo State (Brazil). Ecological Economics, vol. 66, no. 2, pp. 359-370. http://dx.doi.org/10.1016/j.ecolecon.2007.09.008.

AMIN, A. and KONÉ, I., 2015. People and Protected areas: an assessment of cost and benefits of conservation to local people in southeastern Ivory Coast. Society \& Natural Resources, vol. 28, no. 9, pp. 1-16. http://dx.doi.org/10.1080/08941920.2015.1014593.

ANDRADE, D.C. and ROMEIRO, A.R., 2013. Valoração de serviços ecossistêmicos: por que e como avançar? Sustentabilidade em Debate, vol. 4, pp. 43-58.

ARROW, K., SOLOW, R., PORTNEY, P.R., LEAMER, E.E., RADNER, R. and SCHUMAN, H., 1993. Report of the NOAA panel on contingent valuation. Washington, DC: U.S. Department of Commerce, National Oceanic and Atmospheric Administration.

BALMFORD, A., BRUNER, A., COOPER, P., COSTANZA, R., FARBER, S., GREEN, R.E., JENKINS, M., JEFFERISS, P., JESSAMY, V., MADDEN, J., MUNRO, K., MYERS, N., NAEEM, S., PAAVOLA, J., RAYMENT, M., ROSENDO, S., ROUGHGARDEN, J., TRUMPER, K. and TURNER, R.K., 2002. Economic reasons for conserving wild nature. Science, vol. 297, no. 5583, pp. 950-953. PMid:12169718. http://dx.doi. org/10.1126/science.1073947.

BARBOSA, N.P.U., FERNANDES, G.W., CARNEIRO, M.A.A. and JÚNIOR, L.A.C., 2010. Distribution of non-native invasive species and soil properties in proximity to paved roads and unpaved roads in a quartzitic mountainous grassland of southeastern Brazil (rupestrian fields). Biological Invasions, vol. 12, no. 11, pp. 3745-3755. http://dx.doi.org/10.1007/s10530-010-9767-y.
BARRIO, M. and LOUREIRO, M.L., 2010. A meta-analysis of contingent valuation forest studies. Ecological Economics, vol. 69, no. 5, pp. 1023-1030. http://dx.doi.org/10.1016/j. ecolecon.2009.11.016.

BERNARD, E., PENNA, L.A.O. and ARAÚJO, E., 2014. Downgrading, downsizing, degazettement, and reclassification of protected areas in Brazil. Conservation Biology, vol. 28, no. 4, pp. 939-950. PMid:24724978. http://dx.doi.org/10.1111/cobi.12298.

BRASIL. Ministério do Meio Ambiente - MMA, 2014. PPCerrado - Plano de Ação para Prevenção e Controle de Desmatamento e das Queimadas: 2 a fase (2014-2015). Brasília: MMA. 132 p.

CAMPOS, R.F. and FILETTO, F., 2011. Análise do perfil, da percepção ambiental e da qualidade da experiência dos visitantes da Serra do Cipó (MG). Revista Brasileira de Ecoturismo, vol. 4, no. 1, pp. 69-94.

CARSON, R.T., WRIGHT, J., ALBERINI, A., CARSON, N. and FLORES, N., 1994. A bibliography of contingent valuation studies and papers. California: Natural Resource Damage Assessment, Inc.

CARVALHO, A.R., 2007. An ecological economics approach to estimate the value of a fragmented wetland in Brazil (Mato Grosso do Sul state). Brazilian Journal of Biology $=$ Revista Brasileira de Biologia, vol. 67, no. 4, pp. 663-671. PMid:18278318. http:// dx.doi.org/10.1590/S1519-69842007000400011.

COELHO, M.S., ALMADA, E.D., QUINTINO, A.V., FERNANDES, G.W., SANTOS, R.M., SÁNCHEZ-AZOFEIFA, G.A. and ESPÍRITO SANTO, M.M.D., 2012. Floristic composition and structure of a tropical dry forest at different successional stages in the Espinhaço Mountains, Southeastern Brazil. Interciencia, vol. 37, no. 3, pp. 190-196.

COELHO, M.S., RESENDE, F.M., ALMADA, E.D. and FERNANDES, G.W., 2013. Crescimento econômico e a moderna crise ambiental: uma análise crítica. Neotropical Biology and Conservation, vol. 8, no. 1, pp. 53-62. http://dx.doi.org/10.4013/ nbc.2013.81.07.

COSTANZA, R., 2000. Social goals and the valuation of ecosystem services. Ecosystems (New York, N.Y.), vol. 3, no. 1, pp. 4-10. http://dx.doi.org/10.1007/s100210000002.

COSTANZA, R., ARGE, R., DE GROOT, R., FARBER, S., GRASSO, M., HANNON, B., LIMBURG, K., NAEEM, S., NEILL, R.V.O., PARUELO, J., RASKIN, R.G. and SUTTONKK, P., 1997. The value of the world's ecosystem services and natural capital. Nature, vol. 387 , no. 6630 , pp. $253-260$. http://dx.doi. org/10.1038/387253a0.

COSTANZA, R., DE GROOT, R., SUTTON, P., VAN DER PLOEG, S., ANDERSON, S.J., KUBISZEWSKI, I., FARBER, S. and TURNER, R.K., 2014. Changes in the global value of ecosystem services. Global Environmental Change, vol. 26, no. 1, pp. 152-158. http://dx.doi.org/10.1016/j.gloenvcha.2014.04.002.

COSTANZA, R., WAINGER, L., FOLKE, C. and MÄLER, K.G., 1993. Modeling complex ecological economic systems. Bioscience, vol. 43, no. 8, pp. 545-555. http://dx.doi.org/10.2307/1311949.

CRUTZEN, P.J., 2002. The effects of industrial and agricultural practices on atmospheric chemistry and climate during the Anthropocene. Journal of Environmental Science and Health, vol. 37, no. 4, pp. 423-424. PMid:12046643. http://dx.doi. org/10.1081/ESE-120003224.

DALY, H.E. and FARLEY, J., 2004. Economia Ecológica: princípios e aplicações. Lisboa: Instituto Piaget. 530 p. 
DE GROOT, R., BRANDER, L., VAN DER PLOEG, S., COSTANZA, R., BERNARD, F., BRAAT, L., CHRISTIE, M., CROSSMAN, N., GHERMANDI, A., HEIN, L., HUSSAIN, S., KUMAR, P., MCVITTIE, A., PORTELA, R., RODRIGUEZ, L.C., TEN BRINK, P. and VAN BEUKERING, P., 2012. Global estimates of the value of ecosystems and their services in monetary units. Ecosystem Services, vol. 1, no. 1, pp. 50-61. http://dx.doi. org/10.1016/j.ecoser.2012.07.005.

DIAMOND, P.A. and HAUSMAN, J.A., 1994. Contingent valuation: is some number better than no number? The Journal of Economic Perspectives, vol. 8, no. 4, pp. 45-64. PMid:10136765. http://dx.doi.org/10.1257/jep.8.4.45.

FERNANDES, G.W., 2016. Ecology and conservation of mountaintop grasslands in Brazil. Switzerland: Springer International Publishing.

FERNANDES, G.W., BARBOSA, N.P.U., NEGREIROS, D. and PAGLIA, A.P., 2014. Challenges for the conservation of vanishing megadiverse rupestrian grasslands. Natureza \& Conservação, vol. 12, no. 2, pp. 162-165. http://dx.doi.org/10.1016/j.ncon.2014.08.003.

FERREIRA, R.A. and GONTIJO, B.M., 2010. A Serra do Cipó e seus vetores de penetração turística - um olhar sobre as transformações socioambientais. Belo Horizonte: Universidade Federal de Minas Gerais, 152 p. Masters Dissertation.

FIGGIS, P., MACKEY, B., FITZSIMONS, J., IRVING, J. and CLARKE, P., 2015. Valuing nature: protected areas and ecosystem services. Sydney: Australian Committee for IUCN. 140 p.

FOLEY, J.A., DEFRIES, R., ASNER, G.P., BARFORD, C., BONAN, G., CARPENTER, S.R., CHAPIN, F.S., COE, M.T., DAILY, G.C., GIBBS, H.K., HELKOWSKI, J.H., HOLLOWAY, T., HOWARD, E.A., KUCHARIK, C.J., MONFREDA, C., PATZ, J.A., PRENTICE, I.C., RAMANKUTTY, N. and SNYDER, P.K., 2005. Global consequences of land use. Science, vol. 309, no. 5734, pp. 570-574. PMid:16040698. http://dx.doi.org/10.1126/ science. 1111772 .

GEORGESCU-ROEGEN, N., 1971. The entropy law and the economic process. Cambridge: Havard University Press.

GIULIETTI, A.M., MENEZES, N.L., PIRANI, J.R., MEGURO, M. and WANDERLEY, M.G.L., 1987. Flora da Serra do Cipó, Minas Gerais: caracterização e lista de espécies. Boletim de Botânica da Universidade de São Paulo, vol. 9, pp. 152.

GIULIETTI, A.M., PIRANI, J.R. and HARLEY, R.M., 1997. Espinhaço Range region: Eastern Brazil. In: S.D. DAVIS, V.H. HEYWOOD, O. HERRERA-MACBRYDE, J. VILLA-LOBOS and A.C. HAMILTON, eds. Centres of plant diversity: a guide and strategies for the conservation. Cambridge: WWF/IUCN. pp. 397-404.

GOLDMAN, R.L., TALLIS, H., KAREIVA, P. and DAILY, G.C., 2008. Field evidence that ecosystem service projects support biodiversity and diversify options. Proceedings of the National Academy of Sciences of the United States of America, vol. 105, no. 27, pp. 9445-9448. PMid:18591667. http://dx.doi.org/10.1073/ pnas.0800208105.

GUJARATI, D.N., 2000. Econometria básica. 3. ed. São Paulo: Makron Books.

HILL, C.R., GRIFFITHS, W.E. and JUDGE, G.G., 2006. Econometria. 2. ed. São Paulo: Saraiva.

HOYOS, D. and MARIEL, P., 2010. Contingent valuation: past, present and future. Prague Economic Papers, vol. 4, no. 4, pp. 329-343. http://dx.doi.org/10.18267/j.pep.380.
INSTITUTO CHICO MENDES DE CONSERVAÇÃO DA BIODIVERSIDADE - ICMBio, 2009. Plano de manejo do Parque Nacional da Serra do Cipó. Brasília: ICMBIO.

JACOBSEN, J.B. and HANLEY, N., 2009. Are there income effects on global willingness to pay for biodiversity conservation? Environmental and Resource Economics, vol. 43, no. 2, pp. 137 160. http://dx.doi.org/10.1007/s10640-008-9226-8.

KLINK, C.A. and MACHADO, R.B., 2005. Conservation of the Brazilian Cerrado. Conservation Biology, vol. 19, no. 3, pp. 707-713. http://dx.doi.org/10.1111/j.1523-1739.2005.00702.x.

LELE, S., SPRINGATE-BAGINSKI, O., LAKERVELD, R., DEB, D. and DASH, P., 2014. Ecosystem services: origins, contributions, pitfalls, and alternatives. Conservation \& Society, vol. 11, no. 4, pp. 343-358. http://dx.doi.org/10.4103/0972-4923.125752.

LOYOLA, R.D., 2014. Brazil cannot risk its environmental leadership. Diversity \& Distributions, vol. 20, no. 12, pp. 13651367. http://dx.doi.org/10.1111/ddi.12252.

MADEIRA, J.A., RIBEIRO, K.T., OLIVEIRA, M.J.R., NASCIMENTO, J.S. and PAIVA, C.L., 2008. Distribuição espacial do esforço de pesquisa biológica na Serra do Cipó, Minas Gerais: subsídios ao manejo das unidades de conservação da região. Megadiversidade, vol. 4, no. 1-2, pp. 15.

MAIA, A.G., ROMEIRO, A.R. and REYDON, B.P., 2004. Valoração de recursos ambientais: metodologias e recomendações. Campinas: Instituto de Economia, UNICAMP. Texto para Discussão, vol. 116.

MEDEIROS, R., YOUNG, C.E.F., PAVESE, H.B. and ARAÚJO, F.F.S., 2011. Contribuição das unidades de conservação brasileiras para a economia nacional: sumário executivo. Brasília: UNEPWCMC.

MILLENNIUM ECOSYSTEM ASSESSMENT - MEA, 2005. Ecosystems and human well-being. Washington, DC: Island Press.

MIROWSKI, P., 1989. More heat than light. New York: Cambridge University Press.

MORAN, D. and MORAES, A.S., 2002. The economic value of pollution damage in the Pantanal. In: D.W. PEARCE, C. PEARCE, C. PALMER, eds. Valuing the environment in developing countries: case studies. Cheltenham: Edward Elgar. pp. 289-310.

MOTTA, R.S., 1997. Manual para valoração econômica de recursos ambientais. Rio de Janeiro: IPEA/MMA/PNUD/CNPq.

PERSKY, J., 1995. The ethology of homo economicus. The Journal of Economic Perspectives, vol. 9, no. 2, pp. 221-231. http://dx.doi.org/10.1257/jep.9.2.221.

PINDYCK, R.P. and RUBINFELD, D.L., 2009. Microeconomics. New Jersey: Pearson Prentice Hall.

RAPINI, A., RIBEIRO, P.L., LAMBERT, S. and PIRANI, J.R., 2008. A flora dos campos rupestres da Cadeia do Espinhaço. Megadiversidade, vol. 4, no. 1-2, pp. 16-24.

RESENDE, F., FERNANDES, G. and COELHO, M., 2013. Economic valuation of plant diversity storage service provided by Brazilian rupestrian grassland ecosystems. Brazilian Journal of Biology $=$ Revista Brasileira de Biologia, vol. 73, no. 4, pp. 709-716. PMid:24789385. http://dx.doi.org/10.1590/S151969842013000400005 .

RIBEIRO, J.F. and WALTER, B.M.T., 2008. As principais fitofisionomias do Bioma Cerrado. In: S.M. SANO, S.P. ALMEIDA, J.F. RIBEIRO, eds. Cerrado: ecologia e flora. Brasilia, DF: Embrapa Cerrados. vol. 1. 
ROCKSTRÖM, J., STEFFEN, W., NOONE, K., PERSSON, A., CHAPIN, F.S., LAMBIN, E.F., LENTON, T.M., SCHEFFER, M., FOLKE, C., SCHELLNHUBER, H.J., NYKVIST, B., WIT, C.A., HUGHES, T., VAN DER LEEUW, S., RODHE, H., SORLIN, S., SNYDER, P.K., COSTANZA, R., SVEDIN, U., FALKENMARK, M., KARLBERG, L., CORELL, R.W., FABRY, V.J., HANSEN, J., WALKER, B., LIVERMAN, D., RICHARDSON, K. and CRUTZEN, P., 2009. A safe operating space for humanity. Nature, vol. 461, no. 7263, pp. 472-475. PMid:19779433. http://dx.doi. org/10.1038/461472a.

SCHRÖTER, M., ZANDEN, E.H., OUDENHOVEN, A.P.E., REMME, R.P., SERNA-CHAVEZ, H.M., DE GROOT, R.S. and OPDAM, P., 2014. Ecosystem services as a contested concept: a synthesis of critique and counter-arguments. Conservation Letters, vol. 7, no. 6, pp. 514-523. http://dx.doi.org/10.1111/conl.12091.

SILVEIRA, F.A.O., NEGREIROS, D., BARBOSA, N.P.U., BUISSON, E., CARMO, F.F., CARSTENSEN, D.W., CONCEIÇÃO, A.A., CORNELISSEN, T.G., ECHTERNACHT, L., FERNANDES, G.W., GARCIA, Q.S., GUERRA, T.J., JACOBI, C.M., LEMOSFILHO, J.P., LE STRADIC, S., MORELLATO, L.P.C., NEVES, F.S., OLIVEIRA, R.S., SCHAEFER, C.E., VIANA, P.L. and LAMBERS, H., 2016. Ecology and evolution of plant diversity in the endangered campo rupestre: a neglected conservation priority. Plant and Soil, vol. 403, no. 1-2, pp. 129-152.

SPASH, C.L., 2008. The contingent valuation method: retrospects and prospects. Australia: CSIRO Sustainable Ecosystems.
TURPIE, J.K., 2003. The existence value of biodiversity in South Africa: how interest, experience, knowledge, income and perceived level of threat influence local willingness to pay. Ecological Economics, vol. 46, no. 2, pp. 199-216. http://dx.doi. org/10.1016/S0921-8009(03)00122-8.

VAN DEN BERGH, J.C.J.M., 2001. Ecological economics: themes, approaches, and differences with environmental economics. Regional Environmental Change, vol. 2, no. 1, pp. 13-23. http:// dx.doi.org/10.1007/s101130000020.

VATN, A. and BROMLEY, D.W., 1994. Choices without prices without apologies. Journal of Environmental Economics and Management, vol. 26, no. 2, pp. 129-148. http://dx.doi.org/10.1006/ jeem.1994.1008.

VOINOV, A., 2008. Systems science and modeling for ecological economics. London: Elsevier Inc.

WÄTZOLD, F., DRECHSLER, M., ARMSTRONG, C.W., BAUMGÄRTNER, S., GRIMM, V., HUTH, A., PERRINGS, C., POSSINGHAM, H.P., SHOGREN, J.F., SKONHOFT, A., VERBOOM-VASILJEV, J. and WISSEL, C., 2006. Ecologicaleconomic modeling for biodiversity management: potential, pitfalls, and prospects. Conservation Biology, vol. 20, no. 4, pp. 1034-1041. PMid:16922220. http://dx.doi.org/10.1111/j.15231739.2006.00353.x. 